\title{
A molecular marker for in situ genetic resource conservation of Capsicum annuum var. acuminatum (Solanaceae)
}

\author{
N. Kaewdoungdee ${ }^{1}$ and T. Tanee ${ }^{2}$ \\ ${ }^{1}$ Department of Biotechnology, Faculty of Science and Technology, \\ Bansomdejchaopraya Rajabhat University, Bangkok, Thailand \\ ${ }^{2}$ Faculty of Environment and Resource Studies, Mahasarakham University, \\ Mahasarakham, Thailand \\ Corresponding author: T. Tanee \\ E-mail: tawatchai5@hotmail.com
}

Genet. Mol. Res. 12 (3): 3529-3539 (2013)

Received July 23, 2012

Accepted November 10, 2012

Published February 28, 2013

DOI http://dx.doi.org/10.4238/2013.February.28.10

\begin{abstract}
The Thailand cultivar pepper 'phrik man bangchang' (Capsicum annuum var. acuminatum, Solanaceae) was originally cultivated in the Bangchang Subdistrict, Amphawa District in Samut Songkhram Province. The cultivated areas are limited; we verified its distribution in Thailand for in situ 'phrik man bangchang' genetic resource conservation. Samples were collected from the original cultivation area of Bangchang Subdistrict (Or) and were randomly explored in Ratchaburi Province (RB), Khon Kaen Province (KK), and Sakon Nakhon Province (SN). A pure line from The Tropical Vegetable Research Center at Kasetsart University was used as the standard indicator. Two more Capsicum species, C. chinensis and $C$. frutescens, and a species from another genus in the family, Solanum melongena, were included. A dendrogram constructed from random amplified polymorphic DNA fingerprints indicated that the
\end{abstract}


Or, RB, KK, and $\mathrm{SN}$ samples were $C$. annuum var. acuminatum with supportive similarity coefficients of 0.79 to 0.98 . Finally, DNA barcodes, from $p s b \mathrm{~A}-t r n \mathrm{H}$ spacer region, were provided for the 3 wild species, C. annuum var. acuminatum, C. chinensis, and C. frutescens under GenBank accession Nos. JQ087869-JQ087871. The nucleotide variations between species were 0.23 to 0.26 . In summary, 'phrik man bangchang' is still being planted in Bangchang Subdistrict, but only in small areas. The distribution of planting areas is expected to be throughout Thailand.

Key words: Capsicum annuum var. acuminatum; Genetic resources; Molecular markers; Phrik man bangchang

\section{INTRODUCTION}

Capsicum is a genus of the family Solanaceae and is a very important ingredient in the preparation and consumption of Thai food, which includes native and manufactured sources. The quality of processed capsicum products transformation depends on capsaicin, which is a major component of pungency, and carotenoids, which give the capsicum fruit its color. Variations in capsaicin and carotenoids have been considered in several species including the 3 species of the genus Capsicum in Thailand: C. annuum L., C. chinensis Jacq., and C. frutescens L., with several varieties (Smitinand, 2001). A pepper called 'phrik man bangchang' is a Thai cultivar with the scientific name $C$. annuum var. acuminatum, which was originally planted in Bangchang Subdistrict (Or) of Samut Songkhram Province, Thailand.

Boonyamanop (1993) examined capsaicin and carotenoids to evaluate the quality of Thai Capsicum fruits $C$. frutescens and $C$. annuum. The study of these important substances in Thai Capsicum varieties is useful for selecting cultivars that meet the demands for the market and trade. The capsaicin content of $C$. frutescens was $0.47-0.79 \%$ per dry weight; for $C$. annuum, the range was $0.00-0.53 \%$ per dry weight. Visible spectrophotometry revealed the carotenoid content in C. frutescens was $0.23-0.48 \%$ per dry weight and C. annuum contained $0.06-0.55 \%$ carotenoids per dry weight. To our knowledge, this is the first report to examine these important substances in Thai Capsicum varieties, which will facilitate the selection of varieties best suited to meet market demand.

Molecular methods such as polymerase chain reaction (PCR) and DNA barcodes are commonly used for plant verification and identification. A number of PCR-based methods, including random amplified polymorphic DNA (RAPD), simple sequence repeat, intersimple sequence repeat, and amplified fragment length polymorphism, have been widely used to obtain DNA fingerprints and investigate population genetics. DNA fingerprints have been used to support morphological data. The result is a branching diagram called a dendrogram, which serves as the basis for phylogenetic classification (Avise, 1994; Wolfe et al., 1998; Simpson, 2006). Molecular markers of genetic variation are generally independent of environmental factors and are more numerous than phenotypic characters, thereby providing a clearer indication of underlying variation in the genome. Sitthiwong et al. (2005) classified pepper (C. annuum) accessions by using dendrograms constructed from RAPD data. The clustering obtained from RAPD markers was consistent with the 
morphological characteristics of different pepper accessions. The dendrogram divided the accessions into two groups, the first group includes 8 white corolla accessions and the second group includes 1 white with green margin corolla accession and 1 yellowgreen with green-yellow spot corolla accession. Lazaro-Llanos (2005) used restriction fragment length polymorphism to study the DNA markers of 5 Capsicum species found in the Philippines. The variation in $C$. annuum and $C$. frutescens fragmentation patterns was principally due to the difference in size and base composition of their DNA. Hanáček et al. (2009) assessed genetic variability in 41 accessions of red pepper (C. annuиm) using 8 microsatellite markers to construct a dendrogram. Finger et al. (2010) used RAPD markers to study the genetic diversity and morphological and agronomic traits of $49 C$. chinensis accessions.

For sequence divergence of parts of genes or spacer regions, DNA barcoding aims to provide rapid, accurate, and automatable species identification for further plant testing by using a standardized DNA region as a tag. DNA barcodes should be generated as species-specific markers to assure proper identification. The markers can be used on incomplete plant parts including chopped plants, powders, immature plants, and plants lacking flowers. There has been extensive research on the DNA barcoding of plants since it was introduced in 2003 by Dr. Paul D.N. Hebert, a population geneticist at the University of Guelph in Ontario (Hebert et al., 2003). Chase et al. (2007) proposed to use 2 barcoding regions as a standard protocol for barcoding all land plants: the 3 combined regions of the $r p o \mathrm{C} 1, m a t \mathrm{~K}$, and $p s b \mathrm{~A}-t r n \mathrm{H}$ intergenic spacers, or the $r p o \mathrm{~B}, m a t \mathrm{~K}$, and $p s b \mathrm{~A}-t r n \mathrm{H}$ regions. Newmaster et al. (2008) proposed to use $m a t \mathrm{~K}$ and $p s b \mathrm{~A}-t r n \mathrm{H}$ to identify plants in Myristicaceae. Finally, Hollingsworth et al. (2009) at the Consortium for the Barcode of Life plant working group recommended $r b c \mathrm{~L}$ and $m a t \mathrm{~K}$ as the core DNA barcode regions for land plants. However, some researchers used only one region, $p s b \mathrm{~A}-t r n \mathrm{H}$, in Senna species (Monkheang et al., 2011) and medicinal plants identified as Smilax and Cissus species in fresh and dried samples (Kritpetcharat et al., 2011).

Due to the shrinking of agricultural areas, 'phrik man bangchang' is cultivated in small areas of the Bangchang Subdistrict, Amphawa District, in Samut Songkhram Province. For genetic resource conservation, especially in situ genetic resource conservation, this study randomly explore cultivation areas of 'phrik man bangchang' in Thailand to examine where it exists, is endangered, or extinct from the original cultivated area.

\section{MATERIAL AND METHODS}

\section{Plant material}

Capsicum species were randomly explored and collected from Central and Northeastern Thailand. A pure line of 'phrik man bangchang' (C. annuum var. acuminatum) from The Tropical Vegetable Research Center Kasetsart University (P1), Kamphaeng Saen, Nakhon Pathom Province was used as the standard indicator. 'Phrik man bangchang' was collected from the original area of the cultivar in the Bangchang Subdistrict, Amphawa District, Samut Songkhram Province. Identification was made according to Zang et al. (1994), Nasir (2009), and Gonçalves (2011). Voucher specimens were prepared and kept at BK. The research was begun in early 2011. 


\section{DNA extraction}

Total genomic DNA was extracted with the Plant Genomic DNA Extraction Kit (RBC Bioscience). Extracted DNA was examined by $0.8 \%$ agarose gel electrophoresis and ethidium bromide staining. The quality and quantity of DNA were determined by a gel documenting instrument. DNA samples were diluted to a final concentration of $20 \mathrm{ng} / \mu \mathrm{L}$ for use as DNA templates in the PCRs.

\section{DNA fingerprinting by RAPD marker and dendrogram construction}

Amplifications were carried out for Capsicum species and outgroups, each in $25 \mu \mathrm{L}$ reactions consisting of GoTaq Green Master mix (Promega, USA), $0.5 \mu \mathrm{M}$ primer, and $20 \mathrm{ng}$ DNA template. The reaction mixture was incubated at $94^{\circ} \mathrm{C}$ for 3 min then amplified as follows: 35 cycles of $94^{\circ} \mathrm{C}$ for $1 \mathrm{~min}, 40^{\circ} \mathrm{C}$ for $2 \mathrm{~min}, 72^{\circ} \mathrm{C}$ for $2 \mathrm{~min}$, followed by final extension at $72^{\circ} \mathrm{C}$ for $7 \mathrm{~min}$ on a Swift ${ }^{\mathrm{TM}}$ Maxi Thermal Cycler (Esco Micro, USA). Amplification products were detected by $1.2 \%$ agarose gel electrophoresis in Tris-acetate-EDTA buffer and visualized by ethidium bromide staining. The resulting RAPD bands were used to construct a dendrogram according to NTSYSpc 2.10p (Rohlf, 1998).

\section{DNA barcode amplification and sequence analysis}

DNA barcoding of the species-specific samples was performed by PCR with the following primers for the $p s b \mathrm{~A}-\mathrm{trn} \mathrm{H}$ spacer region (5'-3') GTTATGCATGAACGTAAT GCTC and CGCGCATGGTGGATTCACAATCC (www.kew.org/barcoding/update. html; 28 March 2011). Reactions were performed in $25 \mu \mathrm{L}$ consisting of GoTaq ${ }^{\circledR}$ Green Master Mix (Promega), $0.25 \mu \mathrm{M}$ of each primer, and $10 \mathrm{ng}$ DNA template. Reactions were incubated at $94^{\circ} \mathrm{C}$ for $1 \mathrm{~min}$ and amplification was performed as follows: 35 cycles of $94^{\circ} \mathrm{C}$ for $30 \mathrm{~s}, 53^{\circ} \mathrm{C}$ for $40 \mathrm{~s}, 72^{\circ} \mathrm{C}$ for $40 \mathrm{~s}$, followed by final extension at $72^{\circ} \mathrm{C}$ for $5 \mathrm{~min}$.

The specific amplified fragments were sequenced, analyzed, and annotated, then submitted to the GenBank database. Sequence variations were identified in the MEGA5 software (Tamura et al., 2011).

\section{RESULTS AND DISCUSSION}

\section{Species diversity of Capsicum and distribution of 'phrik man bangchang'}

Based on morphological identification, 3 Thai Capsicum species namely, C. annuum, C. chinensis, and C. frutescens were explored (Figure 1). The samples studied are listed in Table 1. Voucher specimens for Thai capsicum species were prepared under collector numbers A. Chaveerach 734-736 and kept at BK. We discovered 'phrik man bangchang' is being cultivated in other provinces of Central and Northeastern Thailand in addition to Bangchang Subdistrict, although in limited areas. 

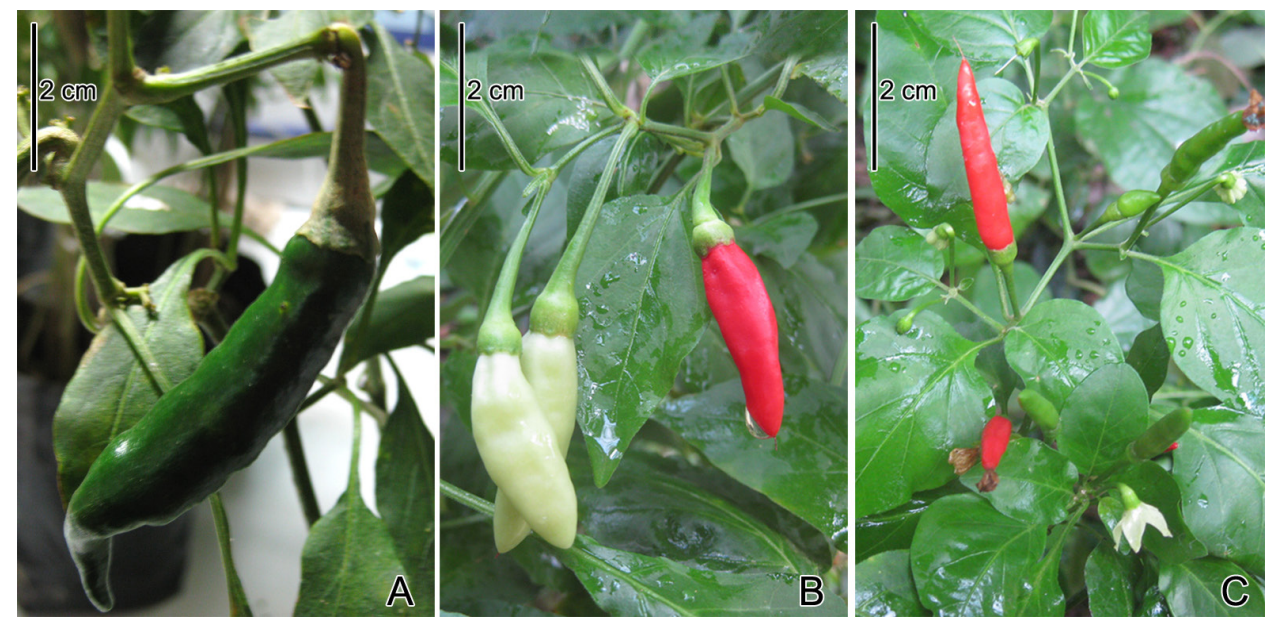

Figure 1. Capsicum species. A. C. annuum var. acuminatum. B. C. chinensis. C. C. frutescens.

\begin{tabular}{|c|c|c|c|c|}
\hline Species & Local name & $\begin{array}{c}\text { No. of } \\
\text { individuals }\end{array}$ & Designated code (remarks) & Source \\
\hline $\begin{array}{l}\text { C. annuum var. } \\
\text { acuminatum }\end{array}$ & 'phrik man bangchang' & 2 & Pl 1, Pl 2 (pure line) & $\begin{array}{l}\text { The Tropical Vegetable Research Center } \\
\text { Kasetsart University, Kamphaeng } \\
\text { Saen, Nakhon Pathom Province }\end{array}$ \\
\hline $\begin{array}{l}\text { C. annuum var. } \\
\text { acuminatum }\end{array}$ & 'phrik man bangchang' & 2 & $\begin{array}{l}\text { Or } 1 \text {, Or } 2 \text { (cultivar from } \\
\text { original area) }\end{array}$ & $\begin{array}{l}\text { Samut Songkhram Province, } \\
\text { Central Thailand }\end{array}$ \\
\hline $\begin{array}{l}\text { C. annuum var. } \\
\text { acuminatum }\end{array}$ & 'phrik man' & 2 & RB 1, RB 2 & Ratchaburi Province, Central Thailand \\
\hline $\begin{array}{l}\text { C. annuum var. } \\
\text { acuminatum }\end{array}$ & 'phrik man' & 2 & $\mathrm{SN} 1, \mathrm{SN} 2$ & $\begin{array}{l}\text { Sakon Nakhon Province, Northeastern } \\
\text { Thailand }\end{array}$ \\
\hline $\begin{array}{l}\text { C. annuum var. } \\
\text { acuminatum }\end{array}$ & 'phrik man' & 3 & KK 1, KK 2, KK 3 & $\begin{array}{l}\text { Khon Kaen Province, Northeastern } \\
\text { Thailand }\end{array}$ \\
\hline C. chinensis & 'phrik kareang' or 'phrik noi' & 2 & (out group) & $\begin{array}{l}\text { Khon Kaen Province, Northeastern } \\
\text { Thailand }\end{array}$ \\
\hline C. frutescens & 'phrik khinu' & 1 & (out group) & $\begin{array}{l}\text { Khon Kaen Province, Northeastern } \\
\text { Thailand }\end{array}$ \\
\hline $\begin{array}{l}\text { Solanum } \\
\text { melongena }\end{array}$ & 'ma khuea' & 1 & (out group) & $\begin{array}{l}\text { Khon Kaen Province, Northeastern } \\
\text { Thailand }\end{array}$ \\
\hline
\end{tabular}

\section{RAPD profiles and cluster analysis}

Thirty-five RAPD primers were screened; the 15 primers that amplified clear bands are as follows (5'-3') GTGATCGCAG, TTCCGAACCC, GTTTCGCTCC, CATCCCCCTG, TTTGCCCGGA, GGACCCTTAC, GTCCCGACGA,TGTCATCCCC, CCCAAGGTCC, AGCGAGCAAG, GAGCGTCGAA, CACAGGCGGA, ACCGCCTGCT, CTGGCGAACT, and GTACGCCCGA. These primers produced 921 bands ranging in size from 100 to $3500 \mathrm{bp}$ as shown in Figure 2. RAPD analysis was used to separate species on different branches of the dendrogram (Figure 3) constructed from the RAPD bands. The dendrogram shows the high efficiency of the RAPD data because it clearly distinguishes species with supportive similarity coefficient (S) as shown in Table 2. The first monophyletic group includes $C$. chinensis and $C$. frutescens and has been divided into subgroups by $\mathrm{S}$ values of 0.65 to 0.72 . The second mono- 
phyletic group consists of all samples called 'phrik man bangchang' and 'phrik man' with $\mathrm{S}$ values from 0.79 (KK 2-RB 1) to 0.98 (SN 1-RB 2). RAPD showed the power of these data for discrimination between Capsicum species. The dendrogram was constructed from banding patterns that were used to sort identical and different species; Or 1, Or 2, RB 1 (Ratchaburi Province), RB 2, SN 1 (Sakon Naknon Province), SN 2, KK 1 (Khon Kaen Province), KK 2, and KK 3 are identical to the standard indicator, C. annuum var. acuminatum (P1 1, Pl 2). Therefore, they are all 'phrik man bangchang'.

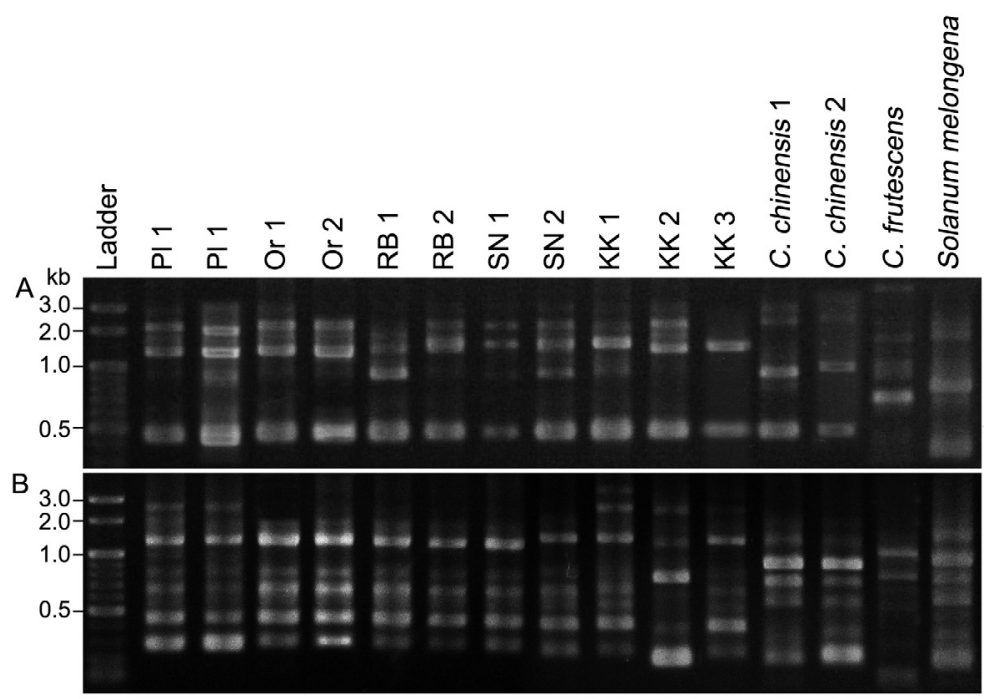

Figure 2. RAPD banding patterns from primers GTCCCGACGA (A) and AGCGAGCAAG (B) of Capsicum annuum var. acuminatum (P1 1-2, Or 1-2, RB 1-2, SN 1-2, KK 1-3) and the other samples studied.

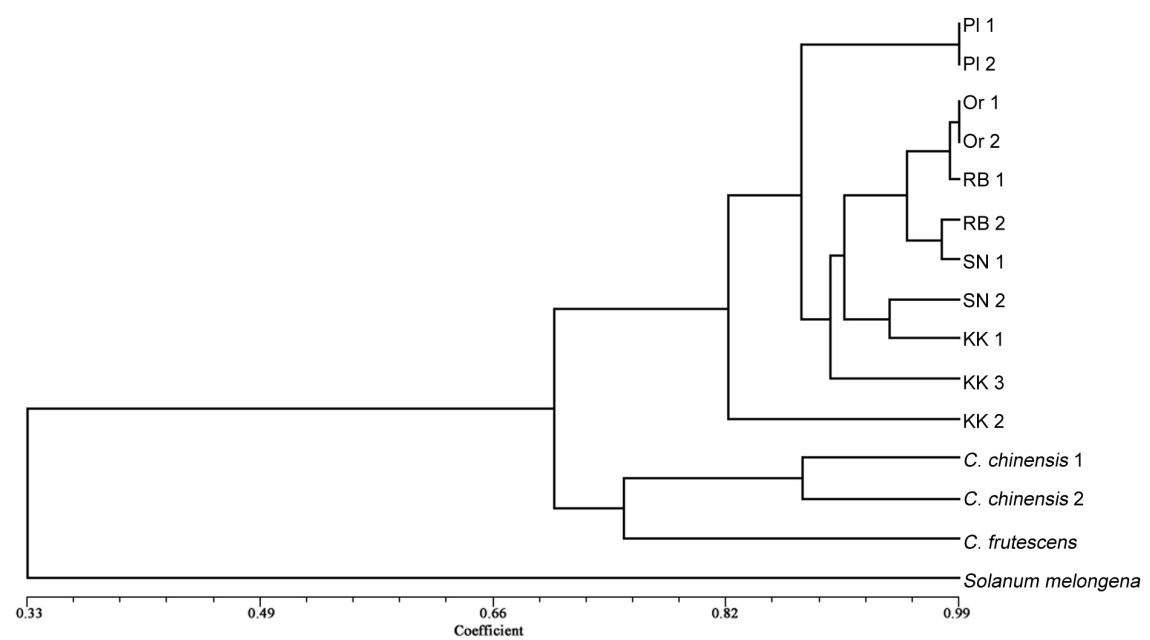

Figure 3. Dendrogram constructed from 15 RAPD fingerprinting data of Capsicum annuum var. acuminatum (P1 1-2, Or 1-2, RB 1-2, SN 1-2, KK 1-3) and the other samples studied by NTSYSpc 2.10p. 


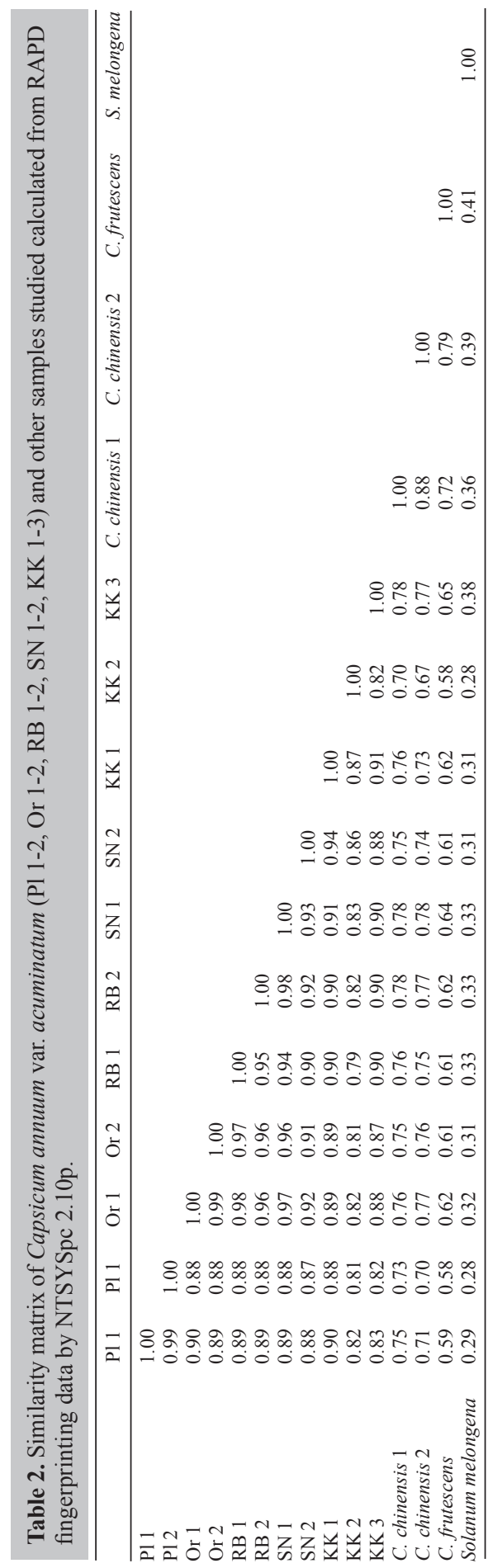


The different species possess lower $\mathrm{S}$ values starting from 0.58-0.59 (C. annuиm var. acuminatum- $C$. frutescens) to $0.70-0.75$ (C. annuum var. acuminatum-C. chinensis). These $\mathrm{S}$ values are consistent with the systematic hypothesis of the evolutionary lines of the monophyletic and polyphyletic groups. Moreover, the results are consistent with the criteria set by Weier et al. (1982).

\section{DNA barcode and sequence variation}

DNA barcodes were successfully created in the standard intergenic $p s b \mathrm{~A}-\operatorname{trn} \mathrm{H}$ region in the 3 species (Figure 4). The sequences were alignment-tested for genetic distances (genetic distances here were implied from nucleotide variations) as shown in Figure 5. Genetic distance values calculated from $p s b \mathrm{~A}-t r n \mathrm{H}$ sequences by MEGA5 were $0.26,0.25$, and 0.23 between $C$. annuum var. acuminatum-C. frutescens, $C$. annuum var. acuminatum-C. chinensis, and C. chinensis-C. frutescens, respectively. These tag sequences were submitted to the GenBank database. GenBank accession numbers and voucher specimens are listed in Table 3.

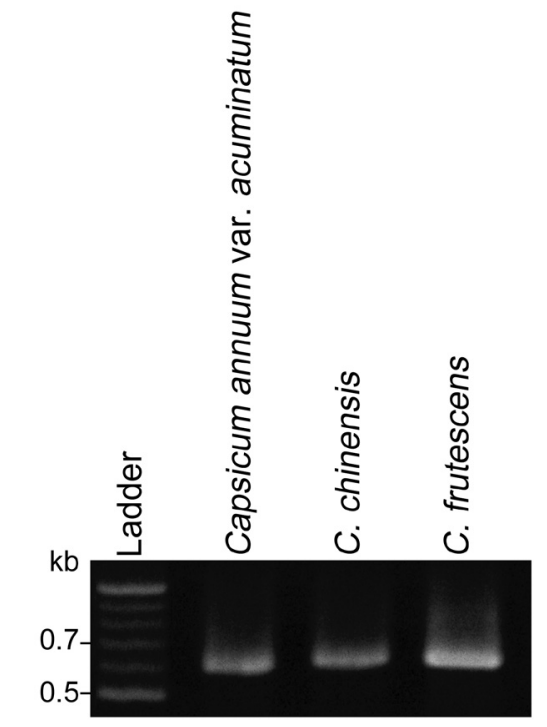

Figure 4. DNA barcode fragments from $p s b \mathrm{~A}-t r n \mathrm{H}$ spacer region of the three Thailand Capsicum species.

Capsicum species are economically important plants and are frequently consumed, especially by Thais. Variable amounts of capsaicin and carotenoids should be considered when identifying species for use in food. Therefore, specific markers are needed for rapid, automatable, and accurate species identification, especially for immature plants lacking flowers or for those with incomplete morphological characteristics that must be verified for large Capsicum farms and grinding fruits. DNA barcoding will serve this purpose. After morphological and fingerprint identification, species-specific barcodes were generated to support the observational evidence. The region was selected based on Monkheang et al. (2011) and Kritpetcharat et al. (2011). The genetic distances of all species studied were sufficiently standardized. These regions contain sufficient variation to discriminate among species. 


Capsicum annuum var. acuminatum
C. chinensis
C. frutescens
C. annuum var. acuminatum
C. chinensis
C. frutescens
C. annuum var. acuminatum
C. chinensis
C. frutescens
C. annuum var. acuminatum
C. chinensis
C. frutescens
C. annuum var. acuminatum
C. chinensis
C. frutescens
C. annuum var. acuminatum
C. chinensis
C. frutescens
C. annuum var. acuminatum
C. chinensis
C. frutescens
C. annuum var. acuminatum
C. chinensis
C. frutescens
C. annuum var. acuminatum
C. chinensis
C. frutescens
C. annuum var. acuminatum
C. chinensis
C. frutescens

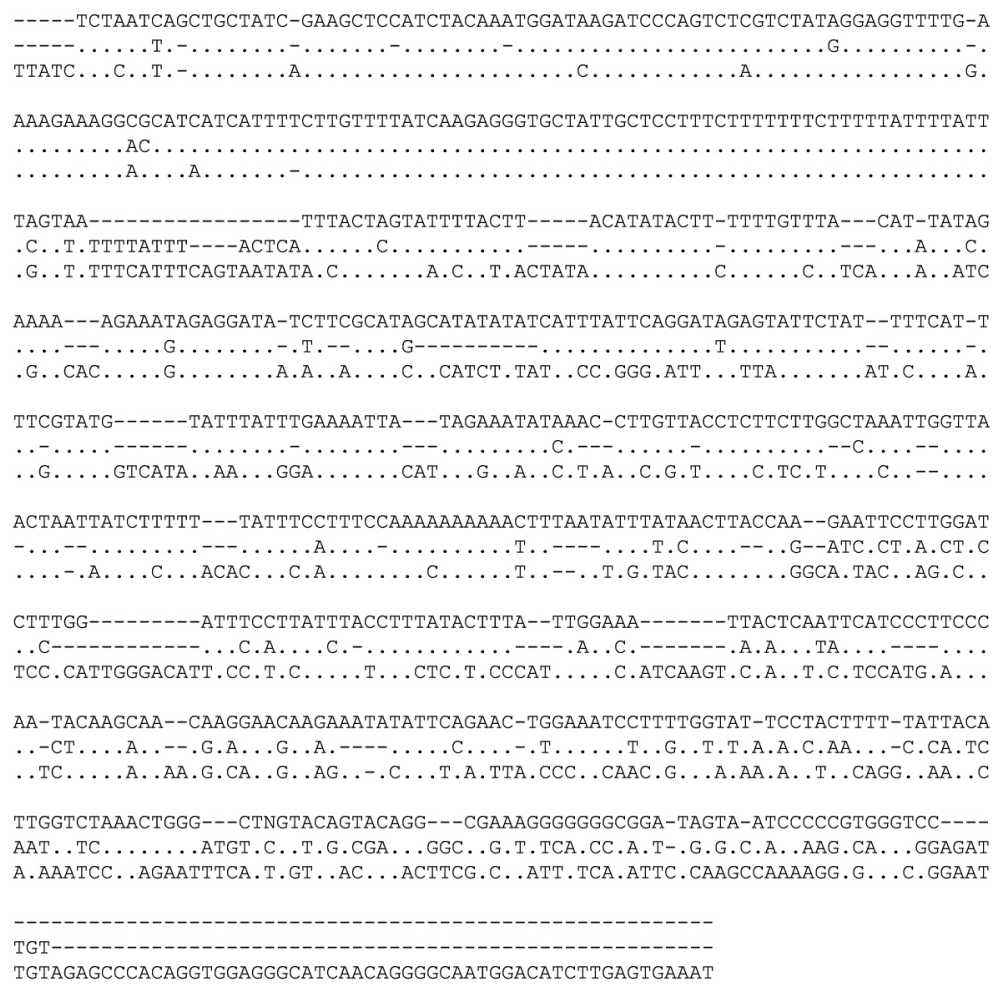

Figure 5. Alignment of $p s b \mathrm{~A}-t r n \mathrm{H}$ spacer sequences of Capsicum annuum var. accuminatum and other two Thailand Capsicum species. (.) = identical nucleotides; $(-)=$ gaps, inserted between the residues so that identical nucleotides are aligned in successive columns.

Table 3. Voucher specimen numbers and GenBank accession numbers of $p s b \mathrm{~A}-t r n \mathrm{H}$ spacer sequences from Thailand Capsicum species.

\begin{tabular}{llr}
\hline Specimen number & Species & Accession No. \\
\hline A. Chaveerach 734 & Capsicum annuum var. acuminatum & JQ087869 \\
A. Chaveerach 735 & C. chinensis & JQ087870 \\
A. Chaveerach 736 & C. frutescens & JQ087871 \\
\hline
\end{tabular}

It is possible to use small sample sizes in molecular studies (Hillis, 1987). Sample sizes in molecular studies are usually much smaller than in morphological studies (often as small as a single individual) because analyses of large sample sizes are often limited by specimen availability or expense. However, the samples studied were randomly collected, which lead to realistic results. Morphological characteristics are normally expressed genetic characters, therefore, are a subset of genomic study. Additionally, variation is limited at the intraspecific and interspecific levels (Weier et al., 1982). All operational taxonomic units, except for barcode sequences of short sequence regions with similarities between 85 and 100\%, might 
be recognized as part of the same species, while a $65 \%$ criterion might be used for the genus level. The DNA barcode, a specific marker for identifying plants using standard sequences, usually uses a single sequence for a species used at the family, genus, and species level of identification and generally has nucleotide variations in intraspecific and interspecific species, whenever applicable by tag comparison. The ultimate interpretation is dependent upon the researchers' knowledge of the included sequences.

We conclude that 'phrik man bangchang' is still being planted in the Bangchang District, but in limited areas. The distribution of planting areas can be expected throughout Thailand since Capsicum is an essential ingredient in Thai food and has a variety of local names such as 'phrik man' or 'phrik chifa'. This has been seen in the randomly collected samples from Ratchaburi, Khon Kaen, and Sakon Nakhon Provinces, which are dependent upon demand and the cost of supplying the markets.

Most studies on Capsicum species genetic diversity focus on banding patterns as described by Sitthiwong et al. (2005), Hanáček et al. (2009), and Finger et al. (2010) with the exception of Lazaro-Llanos (2005), who performed a study on DNA markers for 5 Capsicum species in the Philippines. Therefore, this research will be useful for discriminating Capsicum at the species and variety levels with species-specific barcode markers and for the further identification of some plants lacking parts.

\section{ACKNOWLEDGMENTS}

Research supported by the Bansomdejchaopraya Rajabhat University, Bangkok, Thailand.

\section{REFERENCES}

Avise JC (1994). Molecular Markers, Natural History and Evolution. Chapman and Hall, New York.

Boonyamanop V (1993). Studies on Capsaicin and Carotenoid Contents in Capsicum Cultivars in Thailand. Master's thesis, Chulalongkorn University, Bangkok.

Chase MW, Cowan RS, Hollingsworth PM, Van Den Berg C, et al. (2007). A proposal for a standardised protocol to barcode all land plants. Taxon 56: 295-299.

Finger FL, Lannes SD, Schuelter AR, Doege J, et al. (2010). Genetic diversity of Capsicum chinensis (Solanaceae) accessions based on molecular markers and morphological and agronomic traits. Genet. Mol. Res. 9: 1852-1864.

Gonçalves AE (2011). Solanaceae. In: Flora of Mozambique, Cultivated Plants (Hyde MA, Wursten BT, Ballings P and Dondeyne S, eds.) Available at [http://www.mozambiqueflora.com/cult/family.php?family_id=211]. Accessed September 25, 2011

Hanáček P, Vyhnánek T, Rohrer M, Cieslarová J, et al. (2009). DNA polymorphism in genetic resources of red pepper using microsatellite markers. Hort. Sci. 36: 127-132.

Hebert PD, Cywinska A, Ball SL and deWaard JR (2003). Biological identifications through DNA barcodes. Proc. Biol. Sci. 270: 313-321.

Hillis DM (1987). Molecular versus morphological approaches to systematics. Annu. Rev. Ecol. Syst. 18: 23-42.

Hollingsworth PM, Forrest LL, Spouge JL, Hajibabaei M, et al. (2009). A DNA barcode for land plants. Proc. Natl. Acad. Sci. U. S. A. 106: 12794-12797.

Kritpetcharat O, Khemtonglang N, Kritpetcharat P, Daduang J, et al. (2011). Using DNA markers and barcoding to solve the common problem of identifying dried medicinal plants with the examples of Smilax and Cissus in Thailand. J. Med. Plants Res. 5: 3480-3487.

Lazaro-Llanos N (2005). DNA Markers for Capsicum Species Found in the Philippines. De La Salle University, Manila.

Monkheang P, Sudmoon R, Tanee T, Noikotr K, et al. (2011). Species diversity, usages, molecular markers and barcode of medicinal Senna species (Fabaceae, Caesalpinioideae) in Thailand. J. Med. Plants Res. 5: 6173-6181.

Nasir YJ (2009). Solanaceae. Flora Pak. 168: 23-24.

Newmaster SG, Fazekas AJ, Steeves RA and Janovec J (2008). Testing candidate plant barcode regions in the Myristicaceae. 
Mol. Ecol. Resour. 8: 480-490.

Rohlf FJ (1998). NTSYS pc: Numerical Taxonomy and Multivariate Analysis System Version 2.1. Applied Biostatistics, New York.

Simpson MG (2006). Plant Systematics. Elsevier Academic Press, California.

Sitthiwong K, Matsui T and Sukprakarn S (2005). Classification of pepper (Capsicum annuum L.) accessions by RAPD analysis. Biotechnology 4: 305-309.

Smitinand T (2001). Thai Plant Names. The Forest Herbarium. Royal Forest Department, Bangkok.

Tamura K, Peterson D, Peterson N, Stecher G, et al. (2011). MEGA5: molecular evolutionary genetics analysis using maximum likelihood, evolutionary distance, and maximum parsimony methods. Mol. Biol. Evol. 28: 2731-2739.

Weier TE, Stocking CR, Barbour MG and Rost TL (1982). Botany. John Wiley and Sons, New York.

Wolfe AD, Xiang QY and Kephart SR (1998). Diploid hybrid speciation in Penstemon (Scrophulariaceae). Proc. Natl. Acad. Sci. U. S. A. 95: 5112-5115.

Zang ZY, Lu A and D’Arcy NG (1994). Solanaceae. Flora China 17: 313. 